\title{
MINORITIES RIGHTS PROTECTION IN PUNJAB: AN ANALYSIS OF PRIMARY DATA COLLECTED FROM CHRISTIAN MINORITY
}

\author{
Muhammad Arslan \\ M.Phil. Scholar (Political Science) \\ Government College University \\ Faisalabad - Pakistan \\ arslanjabbar78@gmail.com \\ Dr. Muhammad Shabbir \\ Assistant Professor \\ Department of Education \\ Government College University \\ Faisalabad - Pakistan \\ mskhalid606@yahoo.com \\ Dr. Ghulam Mustafa \\ Assistant Professor \\ Department of International Relations \\ Government College University \\ Faisalabad - Pakistan \\ ghulammustafa@gcuf.edu.pk
}

\section{ABSTRACT}

Pakistan is an Islamic republic as declared the equal rights to every citizen of Pakistan. In Pakistan lot of marginalized groups neglected by the society as they are religious minorities, transgender, special persons etc. In the diverts groups in a country are living and having a lot of issues in toleration of each other identity and that's why the minorities are considered as marginalized. In all constitutions as 1956, 1962 and 1973 that everywhere minorities have mentioned with equal rights especially the constitution of 1973. As article 20 states that every Pakistani citizen have liberty to establish their religious institutions and practice their own religion. With all these equal rights mentioned in constitution the country has lack of implementation of state policies. The purpose of the research is to explore the realities about the Minorities rights and dealing with them by society. The constitution of 1973 provides the guarantee of equal rights 


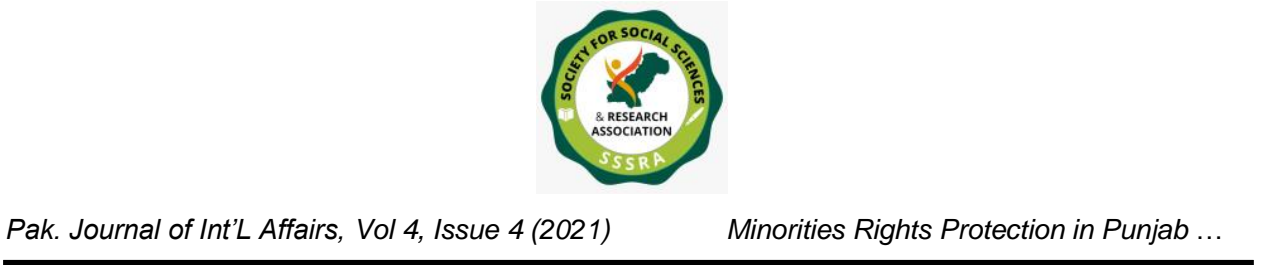

of citizen, but some marginalized groups suppressed by the society. The focus of this research work is to elucidate minorities rights focused on Christian Minority mechanism in Punjab and to explore the difference between theory and practice. The data has been collected from primary and secondary sources. The primary data has been collected through questionnaire. The data was collected from 800 Christian minority people from Punjab. After analysis of data it has come to know that there is a difference in theory and its implications. The government should more focus on minorities rights mechanism and mindset of people should be change towards protection of minorities rights.

Key Words: Minority Rights, Mechanism, Christian, Punjab, Theory and Practice

\section{Introduction}

Human Rights is considered a very vast subject to discuss. It describes in different time in the world history in different perspective. Human rights are like a family of different approaches like Civil Rights, Liberties and other natural and socio-political rights and privileges that belongs to man. The topic human rights come through ages to ages as from the writings of ancient Greek philosophers as Socrates, Plato, and Aristotle etc. So, the rights taken further toward the class distinction that becomes the cause of groupings of people to protect their rights then emerge the shape of groupings like big and small. Under this group distinction the people divided themselves through identities that differ from each other. With this distinction and different identities these groups considered as majorities and minorities.

This research study is conducted explicitly in the context of Pakistan's Constitution, 1973, and Quaid's speech of $11^{\text {th }}$ August 1947 that defines the certain freedoms and liberties for the religious minorities of Pakistan. The Constitution of Pakistan, 1973, has special provisions for the vulnerable segments of society that allow the political participation of religious minorities, share in the civil services and administration. So far as the population of religious minorities is concerned, religious minorities constitute $3.7 \%$ of the total population (Hanif \& Chawla, 2020). Since the creation of Pakistan, there were a significant number of people who opted to live in Pakistan. As far as the remedies to accommodate religious minorities is concerned, the Constitution of Pakistan, 1973, reserved ten seats on separate electorate basis. In the similar manner, the religious minorities have $5 \%$ reserved quota in jobs, and in $2 \%$ quota in higher education as well. In the context of political rights, the electoral reform introduced by General Pervaiz Musharraf regime has sustained the reserved ten (10) seats - out of 342 - for the minorities 


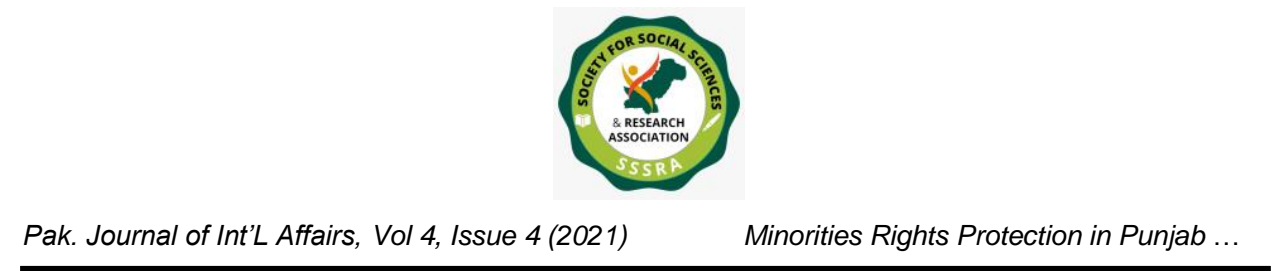

in the National Assembly. As the constitution of Pakistan 1973 transformed the unicameral to bicameral parliament system that has introduced Senate as upper house (Hussain, 2019), therefore, this house reserved four (04) seats - out of 100, for the religious minorities (Mehdi, 2010). However, in the provinces the ratio is different as in Punjab 8 seats, Balochistan 3 seats, Sindh 10 seats and Khyber Pakhtunkhwa 4 seats.

\section{Statement of Problem}

The Constitution of Pakistan has given the equal rights to every citizen of Pakistan, but the religious minorities of Pakistan are marginalized and suppressed by the society because of social injustice. The main purpose of this research is to see the gap rights given by the constitution and their implications from the government and society in Punjab.

\section{Objectives of the Study}

The research topic is linked with SDG \# 5 (Gender Equality) and SDG \# 10 (Reduce Inequalities). Since the SDG \# 5 and SDG \# 10 deals with Gender Equality and removing the inequalities therefore the research topic would address the measures taken to incorporate the SDGs into the domestic legislation and allocated resources including human and financial. In addition, the research topic would also discuss the strategies adopted to ensure the achievements of the SDGs in the set time frame. The literature review, obviously, include the summary document of SDGs published by the Ministry of Planning and Development and Strategic Planning Document with Short term goals and long terms goals will also be analyzed.

The main purpose of this research is to:

i. To address the policy issue that are enhancing the disparity and social disharmony that apartheid the Pakistani nation.

ii. To draw the attention of the decision makers and influencers towards the gross violations of the rights of marginalized sections for the resolves.

iii. To identify and highlight social practices towards marginalized sections that are increasing their vulnerability and invite the attention of concerned stakeholders to ensure legal covers.

\section{Hypotheses}

H1: Despite constitutional guarantees, Minorities are facing multiple discriminations due to in-attention of policy makers and feeble implementation mechanism.

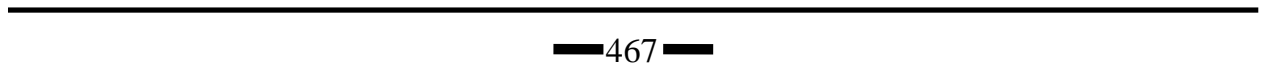




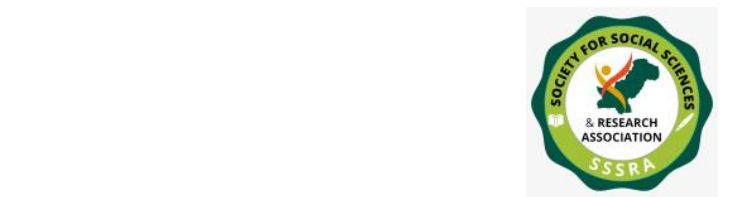

\section{Research Questions}

1- Are religious minorities satisfied with the reserved seats in electoral system?

2- How much difficulty in grass root level representation against majority groups?

3- Did minorities feel discrimination in constitutional \& legal affairs of life?

\section{Research Methodology}

This study would be combination of qualitative and quantitative methods. The Primary and Secondary data has been collected to investigate and analysis the topic. To probe the rights given by the constitution, the researcher has to rely of Constitution of 1973 and different amendments of the constitution. Secondary date has been collected from books, articles published in national or international journals. For this purpose, the researcher visited different libraries like Allama Iqbal Library Lahore, Libraries of University of Punjab, Quaid-e-Azam University Islamabad and different other Libraries.

To get knowledge form the grass root level, the researcher designed the questionnaire and collected data from 800 samples within the Punjab Province territory. So, both Qualitative and Quantitative tools of research have been used to complete this research.

So, for this study, a compound mixed approach has been opted, consisting of official records, documents, analysis of the available data, media resources, reports, discussion papers, surveys within Punjab Province.

\section{Target population}

The target population for this research is people of Christian Minority within the Province of Punjab.

\section{Limitation of the Study}

This research has been limited to Minorities rights especially Christians, within Punjab Province.

\section{Review of Literature}

The issue of religious minorities - specifically in the context of human rights, is not new. Several writers, political activists, human rights defenders, and research scholars have 


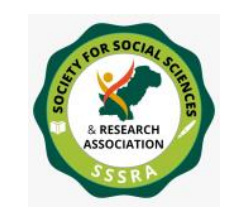

Pak. Journal of Int'L Affairs, Vol 4, Issue 4 (2021)

Minorities Rights Protection in Punjab ...

already produced affluent material on it. Such work as already done by the other scholar helped a lot to understand the context of Pakistan, political approaches, and social behaviours towards religious minorities in Pakistan. Though the researcher has not adopted any new technique and approach, the dimension to discuss the issue of religious minorities in the context of human rights framework and fundamental rights is unique that have exposed the protection measures' realities and state of religious minorities in Pakistan. Following is mentioned the work of different writers that have been used in the research assignment under review.

"Protection of Minority Rights: An Analysis of Implementation of States, Policies, and Illegalities in Pakistan" (2018) is written up by Iffat Tahira, Abdul Qadir Mushtaq published by Journal of the Punjab University Historical Society (JPUHS). The research indicates the minority situation and their worth for Pakistan by examining the facts that happened with the minorities in different decades since the inception of Pakistan. This article focused on the positive and negative aspects of the legislation. It condemned the 1956 legislation as the non-Muslim member cannot be the head of the state and government. It is a descriptive study that is the only basis on the historical incidents and legislation that happened but does not touch the current status that why it has a gap from the problem (Tahira \& Mushtaq, 2018)

"Effectiveness of Local Government System, Pro-poor Budgeting, and Policies for Marginalized Communities" (2020) is the research paper taken from the HEC Project written by Dr. Ghulam Mustafa, Naseem Anthony, and Muhammad Arslan, which was published in the Journal of Pakistan Social Sciences Review (PSSR). The research is focused on the grassroots-level issues of marginalized sections and their representation in local government. The research study under the light of the international agreements as Sustainable Development Goals (SDGs) also mentioned reducing inequality and effort to promote gender equality. This study explored the problems related to marginalized sections at the grassroots level and developed an analytical study with ground realities. There is a lack of representation of minorities and a lack of toleration by society. The study is a great effort to highlight these issues with some recommendations about to counter these issues (Mustafa, Anthony, \& Arslan, 2020).

"Minorities in Pakistan: An Analytical Analysis of the 1973 Constitution of Islamic Republic of Pakistan" (2020) is an analytic paper which is the joint effort of Dr. Ghulam Mustafa, Tooba Ahmad, and Muhammad Arslan. The well-reputed and renowned Journal, i.e., Pakistan Social Sciences Review (PSSR) published it. The Research paper focuses on the constitutional rights given to the religious minorities in detail in all constitutions of Pakistan, while in constitutions of 1973 is elaborated these rights in detail with different 


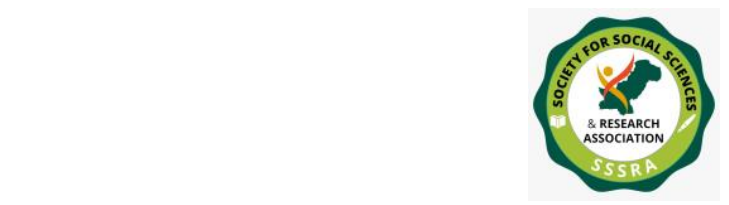

articles. Quaid's vision has declared equality for everyone without any discrimination. The study elucidates the chasm between the given rights to the religious minorities and their lack of implementation. The radicalization in Pakistan with the war against terrorism influenced the minorities in general and religious minorities in specific (Mustafa, Ahmad, \& Arslan, 2020).

"Religious Minorities in Pakistan" (2002) is the write-up of Dr. Iftikhar H. Malik and published by Minority Rights Group (MRG) International. This report focuses on both ethnic and religious minorities. This report elucidates the causes of less development of religious minorities with the political instability of the country and the military intervention. This report highlighted the various parts of the minority issues of Pakistan but also neglected their fundamental rights that given in the constitution (Malik, 2002).

\section{Interpretation of Primary Data}

The research study has focused on religious minority groups, i.e., Christians. The researcher has approached 800 Christians. Furthermore, during the research study, the component of gender inclusion was considered concerning it the graph mentioned define it clearly. The interpretation of primary is as under. The data was collected from seven cities of Punjab province, namely Lahore, Faisalabad, Nankana sab, Chiniot, Toba takes Singh, Multan, and Narowal.

Faisalabad: The Faisalabad city is previously known as Lyallpur, named after the city's creator, is the 3rd most populous city in Pakistan after Lahore and Karachi, respectively, and the second-largest city in the eastern province of Punjab. According to the 2017 census, Faisalabad's population is 3.204 million. Thereby, 353 Christians and 5 Sikh people under the total number 358.

Nankana Sahib: A city in Punjab of province sacred for the Sikh Community. The population of the city, according to the census of 2017 its population is 79,540. It is the most important religious site for the Sikh religion. Therefore, 49 Sikh community members and 05 Christian community members took part in this survey.

Chiniot: Is the 28th largest city of Pakistan. The city population, as per the 2017 census, is 278,747 . The city is famous for wooden furniture. The thing is that only 02 Sikh respondents became part of the survey.

Narowal: The city is part of Punjab, Pakistan, and is the capital of the Narowal district. It is the 94th largest city in Pakistan. It is also known as the house of knowledge. 


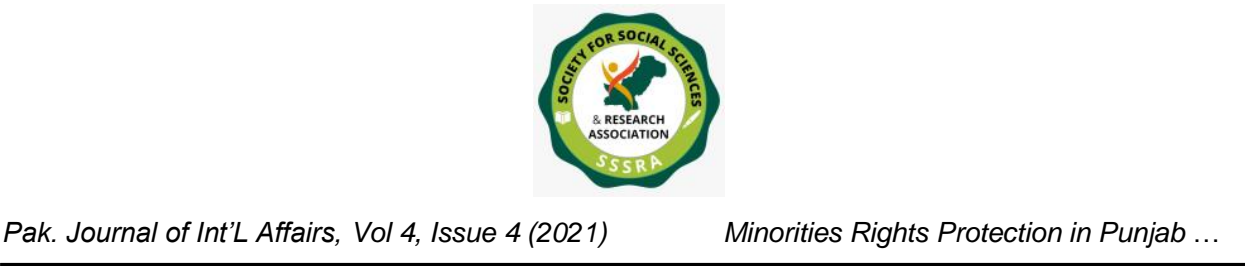

Its population is 103,067 , according to the census of 2017. Thereby, 23 Hindu and 5 Sikh respondents are part of the data.

Lahore: Lahore is the 2nd largest city in Punjab. It is the capital of Punjab province. The total population of Lahore under the 2017 census is 3,655,774. A survey was conducted in Lahore by which recorded figures of Christian were of 245 peoples, 18 Hindu and 38 Sikh participated in the survey.

Multan: Multan is the seventh-largest city of the Punjab division. The city Multan has been colonized for at least 2000 years. According to the 2017 census, the total amount of people was 4745,109 in Multan city. as claimed by a survey conducted in Multan, the queries were asked by the people of minorities and the recorded figure of 102 Christian community, 25 Hindu were part of the survey.

In this regard, the collective data shows that all the participants respond the questions clearly. The targeted people from the selective communities 800 Christians 625 females and 175 males, 120 Sikh 112 males and 08 females and 80 Hindus 53 males and 27 females were total 1000 respondents. Similarly, 660 females and 340 male members from 1000 became part of this research. The reason behind involving females in the survey is to know their views on general topic related to the minorities.

\section{Equal Social Treatment}

The targeted people of Christian minority community were 800 members 175 males and 625 females. In this regard, the majority of 550 people 465 females and 85 males fall under that category 'No' which shows that according to that data the people who select the portion are not enjoying the equal opportunities as compared to the majority community groups. On the other side, 157 minority members 102 females and 55 males became agreed that they are fully enjoying the equal social treatment as the other communities of the country are enjoying and the left category secured 93 people 58 females and 35 males pick the portion 'Do Not Know' which means that they do not know anything about the asked query.

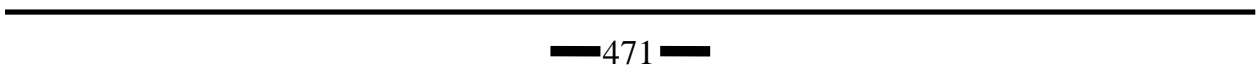




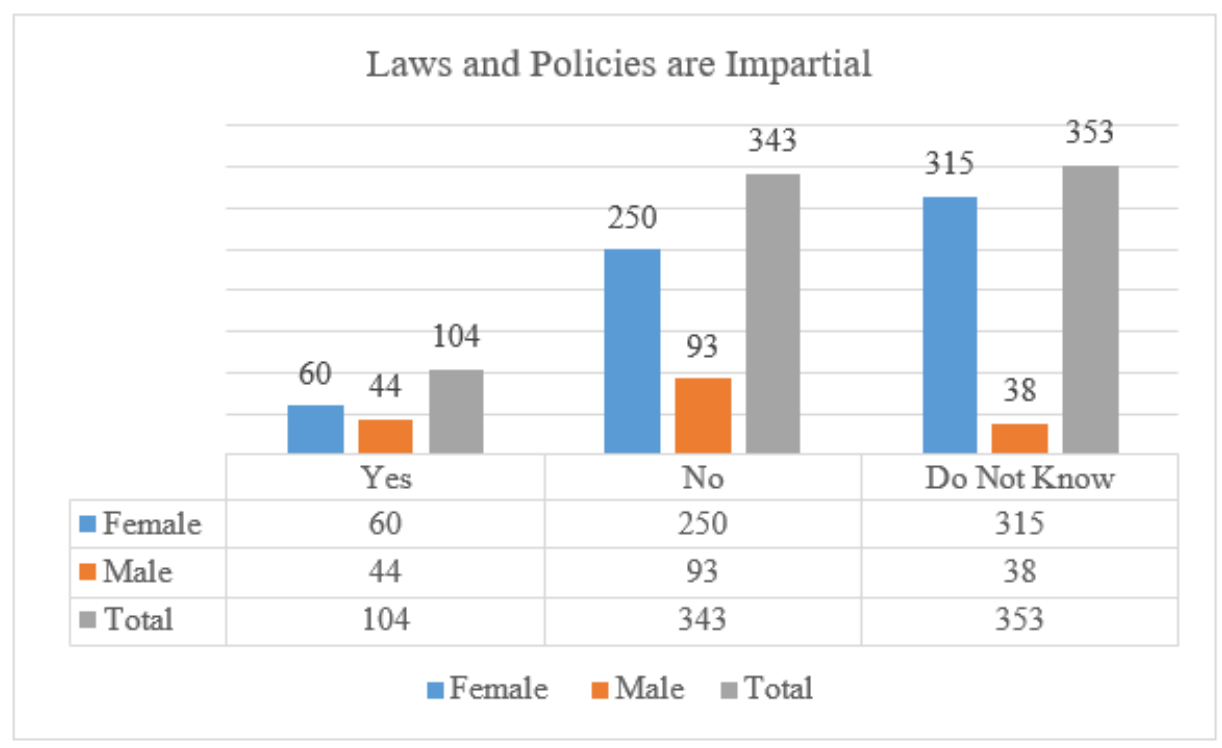

\section{Laws and Policies are Impartial}

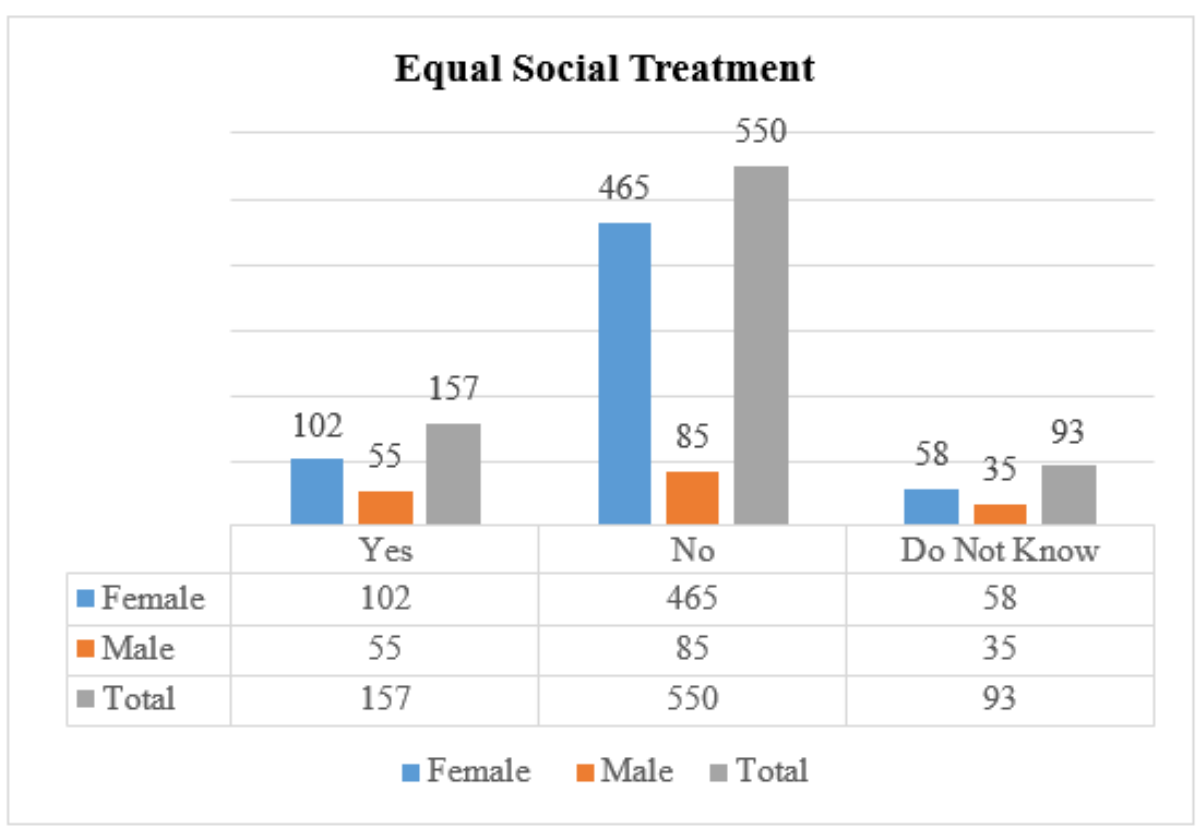


The question was asked to 800 targeted Christian minority people how many minority members believed that the law and policies treated the minority and majority equally. The majority of people who fall under the category 'Do Not Know' are 353 respondents (315 females and 38 males), demonstrating they are unaware of the question. Similarly, the people who picked the option 'No' were 343, including 250 females and 93 males, as they believe that the laws and policies do not treat Muslims and non-Muslims equally. The last category in which respondents agreed and chose 'Yes' are 104 people, of which 60 females and 44 males.

\section{Knowledge of Fundamental Rights}

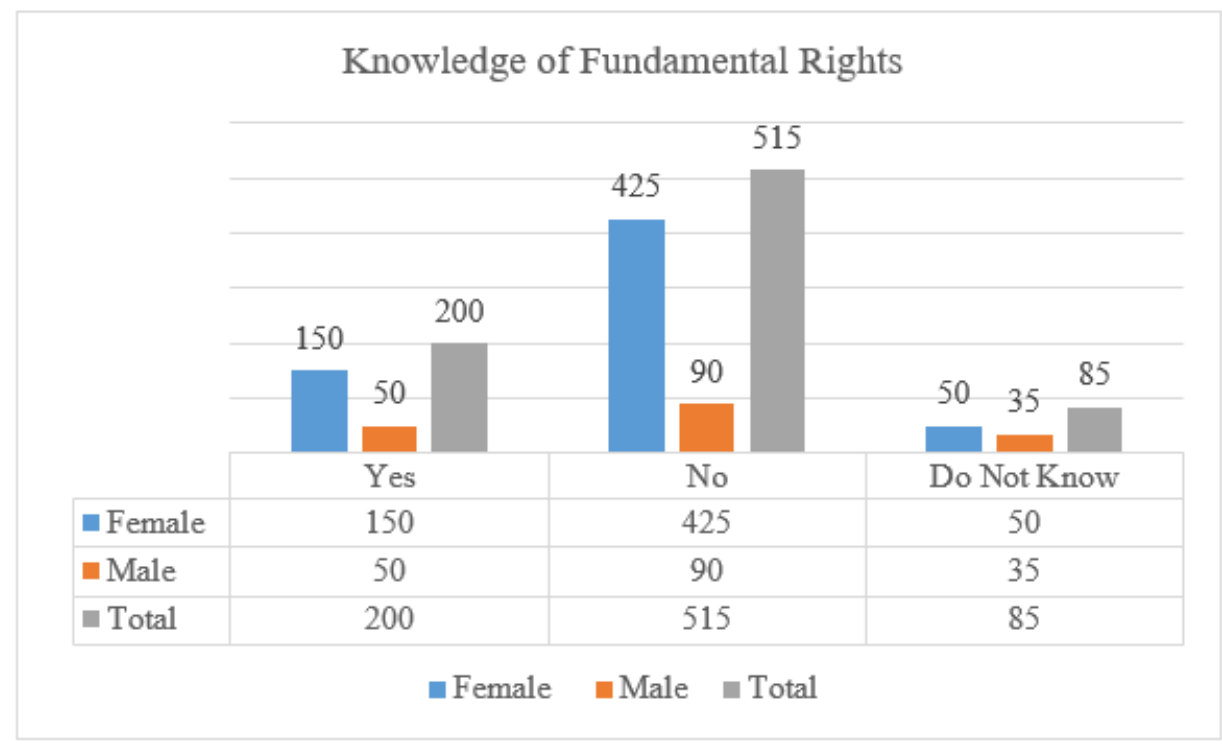

The reason behind posing the question in the survey data is to know the people's views about the constitutional rights of religious minorities. In this regard, the query was asked to 800 Christian minority people. The majority of people selected the option 'No' under 515, in which 425 females and 90 males strongly disagreed. On the other hand, the people who agree and pick the option 'Yes' are 200, including 150 females and 50 males, as they know about the constitutional rights of religious minorities. Similarly, the data collection process recorded 85 persons under 'Do Not Know' in which 50 female and 35 male members are neutral.

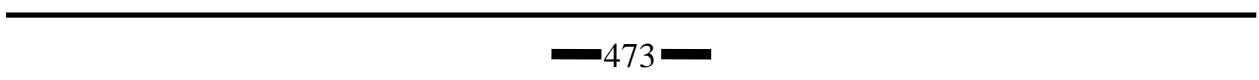




\section{Inclusion of Minorities in Constitution}

The reason behind the question is to assess that to what extent our constitution is accommodating religious minorities. Hence, the collected data shows that most respondents chose the portion 'Do not Know' as of 573 (478 females and 95 males) figure demonstrating that females have less knowledge about constitutional rights. In the second portion, 'No', 124 respondents (100 females and 24 males) picked this category. It shows that respondents disagree regarding the inclusion of religious minorities in the constitution of Pakistan. Therefore, 103 minority members, 56 males and 47 females, picked the category 'Yes' as they think that the constitution of Pakistan has appropriately accommodated the religious minorities.

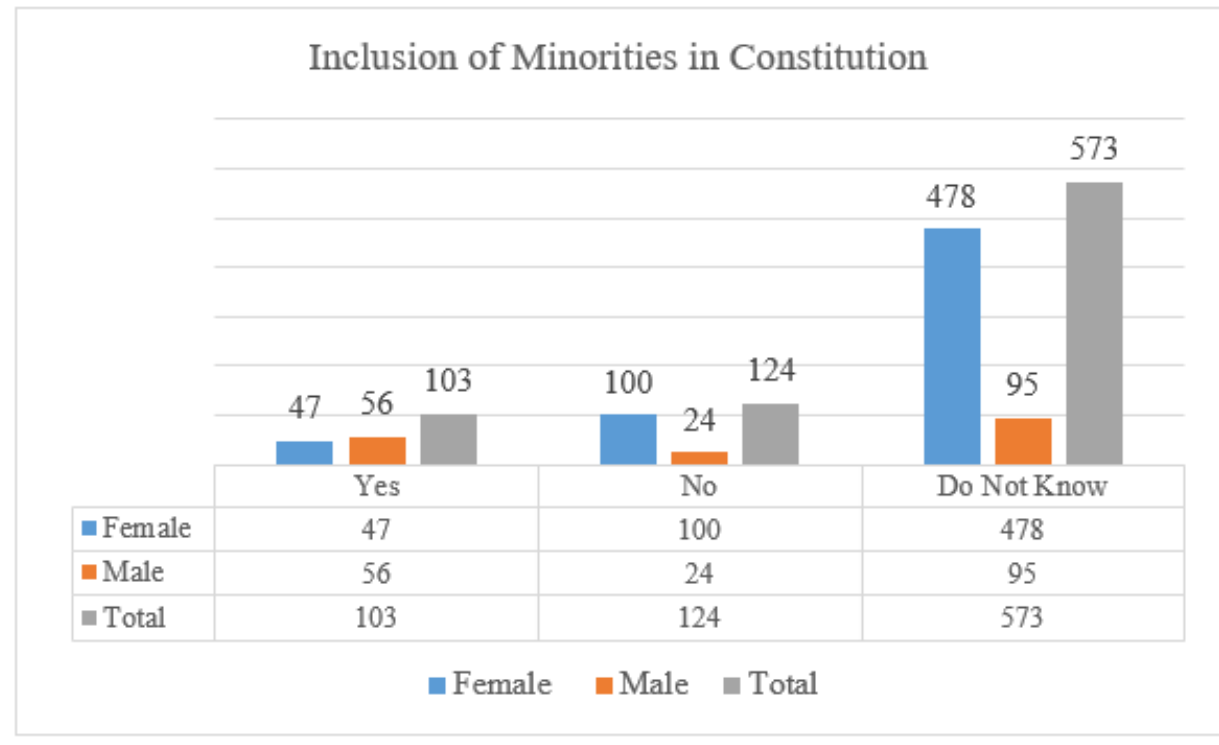

\section{Reserved Quota for Minorities}

When the question is asked to the targeted people the majority of the members were agreed as 436 persons including 350 females and 86 males selected the category 'Yes'. The said portion of respondents were agreed upon the reserved quota of minority and think believe that the policy of reserved quota would protect the rights of minorities and empower them. On the other hand, the category 'No' secured 199 persons 150 women and 49 men, as they denied. The rest portion of respondents who are 165 in which 125 females and 40 males tick the category 'Do Not Know' as they have no idea about the reserved quota for minorities and the rest of the portion. 


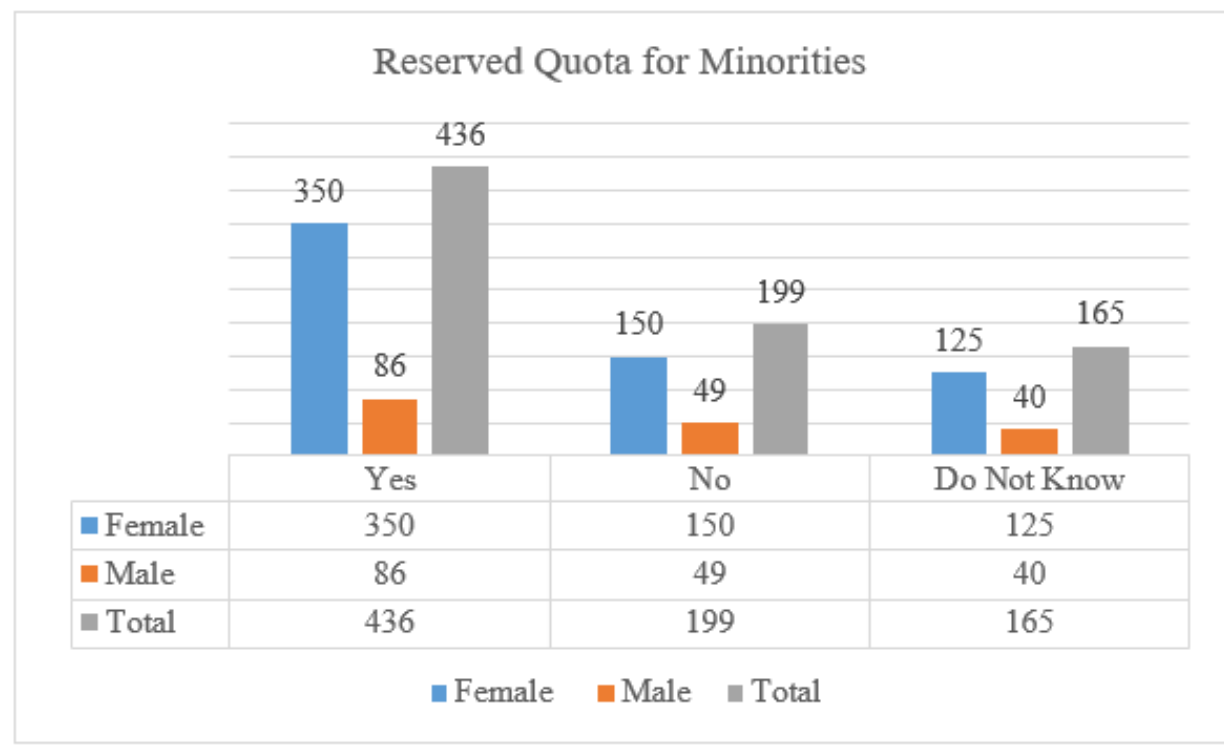

\section{Religious Identity and Vulnerability}

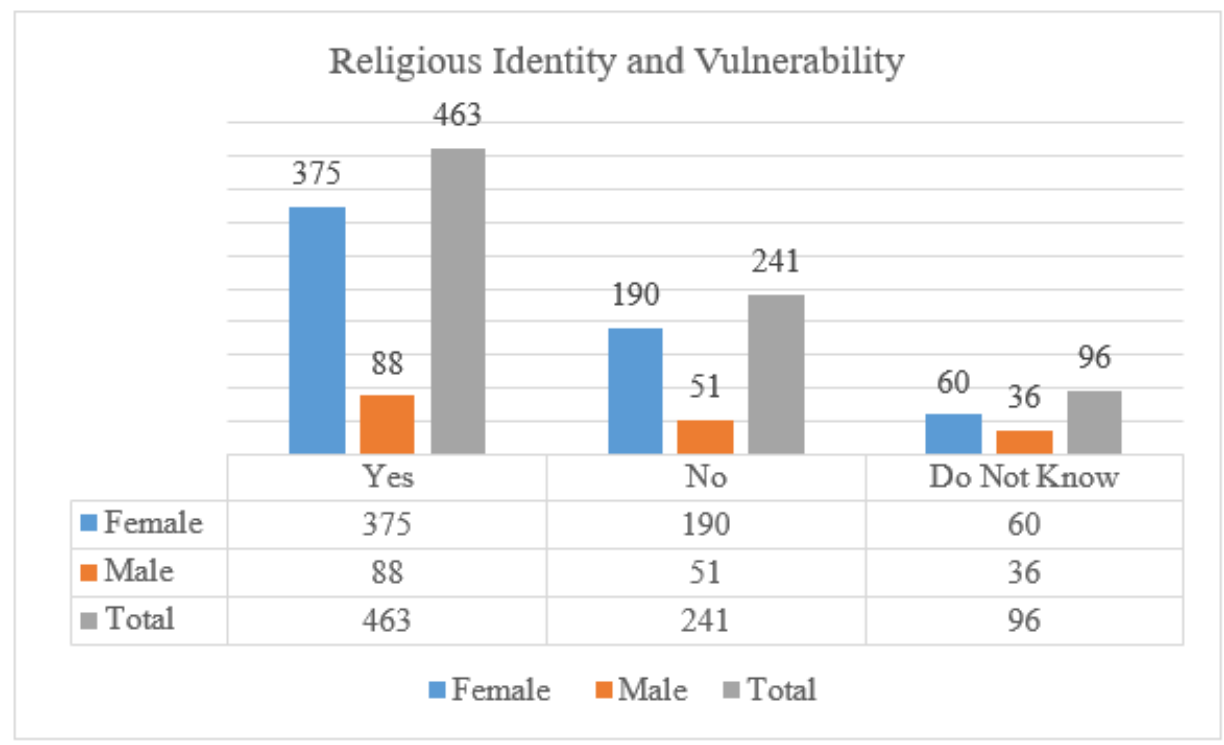


The response of the people against the question regarding religious identity contributed to the increased vulnerability of non-Muslims. It was recorded 463 in which 375 females and 88 males in category 'Yes' as they fully agreed that religious identity is the cause of vulnerability with non-Muslims. However, 190 females and 51 males picked the portion 'No' under the total number of 241. According to their perspective, nonMuslims are enjoying fundamental rights despite their religious identity. Further, the last category of the 'Do not know' portion secured 96 respondents with 60 females and 36 males as they were neutral about the query.

\section{Socio-Political Context}

The research study has investigated the component of socio-political context whether it is conducive for non-Muslims. It was revealed that the majority of people picked the category 'Do not know' owing to unfamiliarity with it. In this respect, the total respondents under this category are 443, 358 female and 85 male members of the Christian community. While the category of 'No' secured 277 respondents, 205 women and 72 men, as they disagreed about claiming that socio-political context allows the minorities to discuss their issues in the parliament. In the same manner, the portion 'Yes' were recorded the 80 respondents, including 62 females and 18 males, showing that the socio-political context allows the minorities to discuss their issues in the parliament.

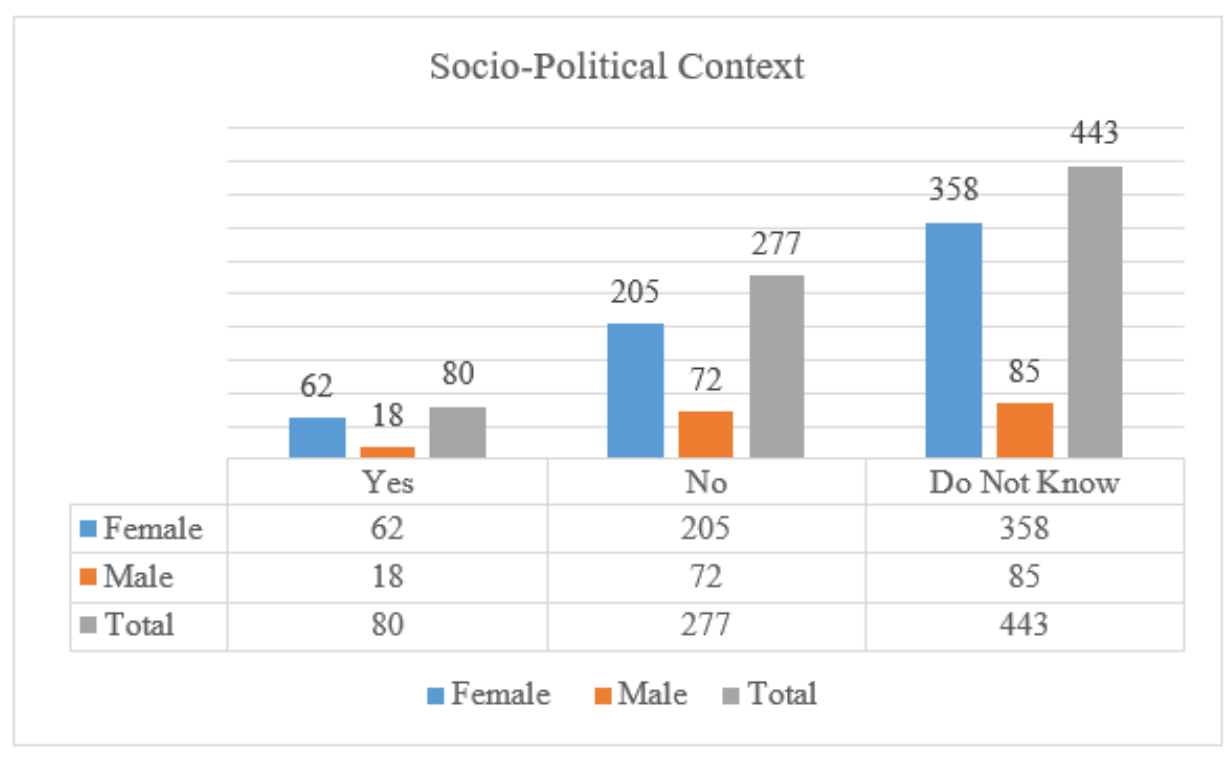




\section{Performance of Institutions}

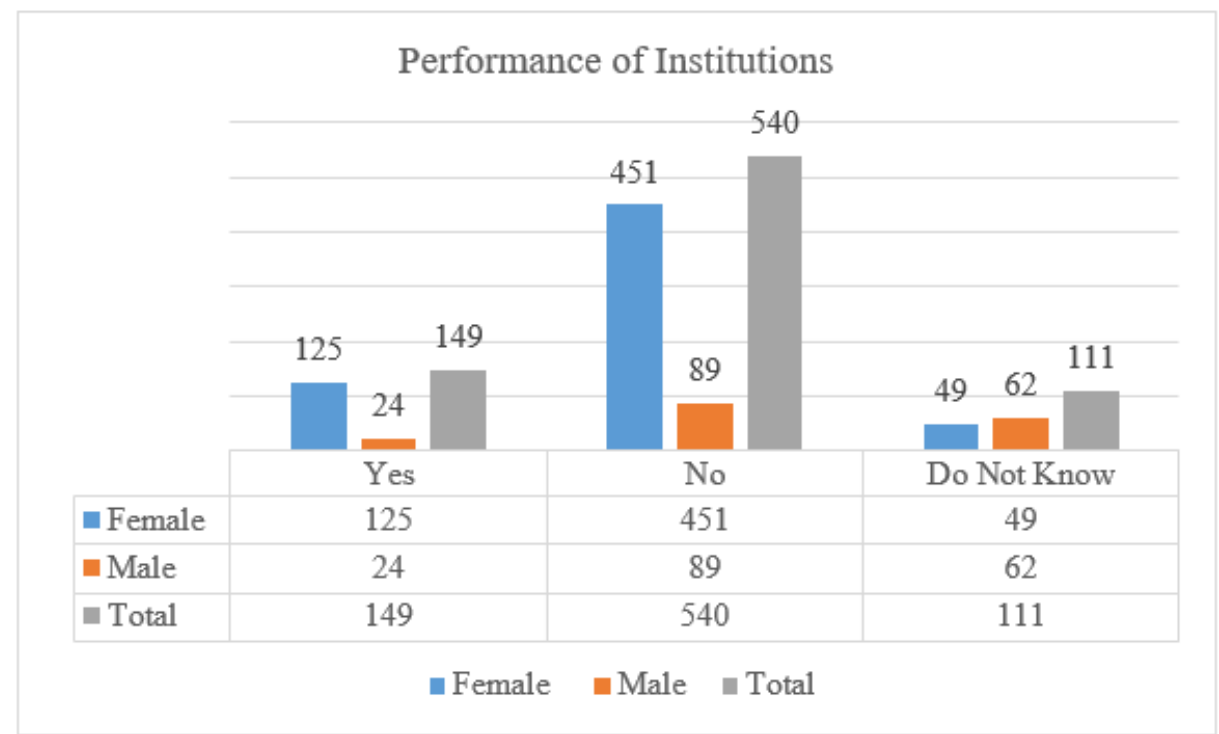

The people's response against the question secured 540 respondents regarding the category of 'No' 451 female and 89 males who were denied that the ministries and department are not concerned with religious minorities and are not performing as per the aspiration of minorities. Therefore, the other category, 'Do Not Know,' was chosen by 111 people, 62 males and 49 females. The ratio of this category shows that 111 people of the targeted minority community did not know the asked question. The last portion of the question's category secured 149 responses (125 females and 24 males) as they opted for the option 'Yes.' it highlights that they were fully aware of the query. They said that they agree and accept that the ministries and departments concerned with religious minorities are performing as per the aspiration of minorities.

\section{Exclusive Ministries/Departments}




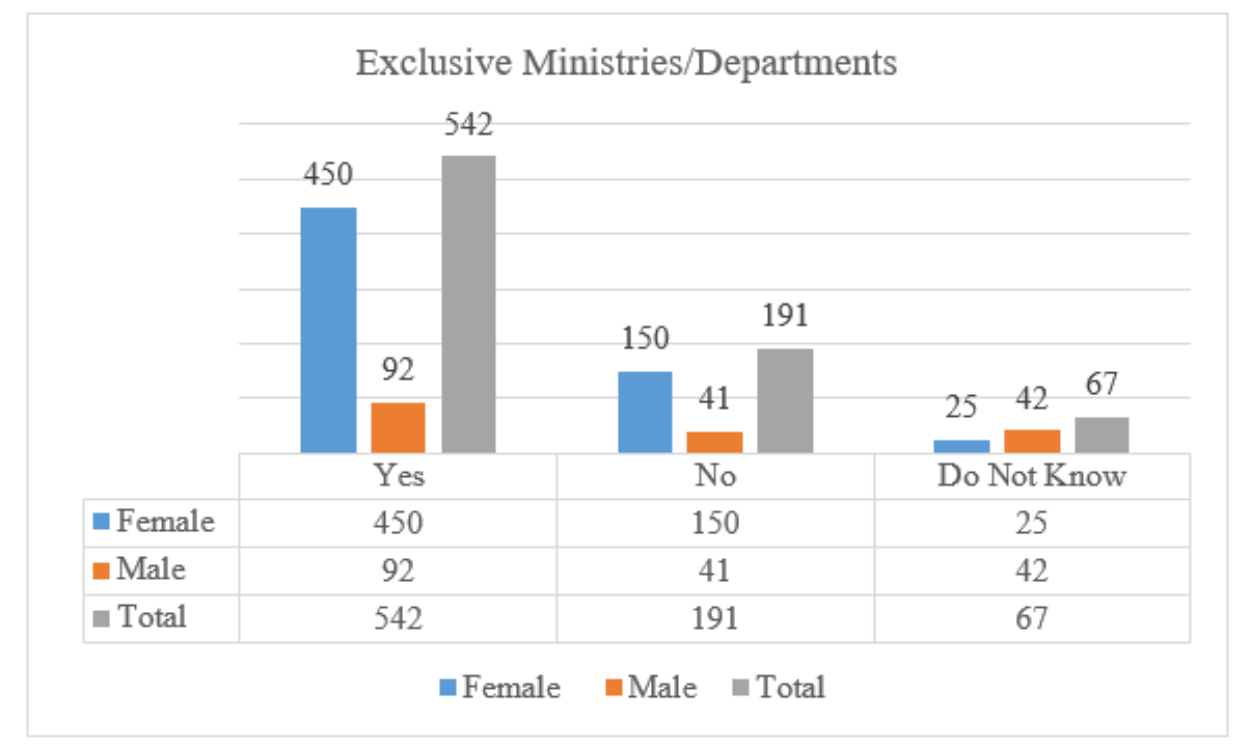

According to the survey data, the majority of 542 minority people 450 females and 92 males, select the portion 'Yes' as they think that the exclusive ministries and departments for minorities would point out the issues of minorities. On the other hand, 191 people, 41 males and 150 females, pick the category 'No', which shows that they deny the performance of departments for minorities, and they are not addressing the issues of minorities. Further, the left portion, 'Do Not Know,' was only selected by 67 members, 42 males and 25 females.

\section{Performance of NHRIs}

The research study and survey data were also aiming to collect people's views regarding the preference of NHRIs institutions. The question related to ti was raised among 800 Christians. Hence, the collective data shows that 557 people, 470 females and 87 males think that the National Human Rights Institutions are not treating the issues of human rights violations of minority communities impartially. Further, 151 targeted members, 56 males and 95 females pick the option 'Do Not Know', which shows that they had no idea and knowledge about the query. The last portion was selected by 92 people (32 males and 60 females). Therefore, according to the data, only 92 members out of 800 think they are aware of the NHRIs and know that these institutions are partial in their operations, specifically in forced conversions and violence against minorities.

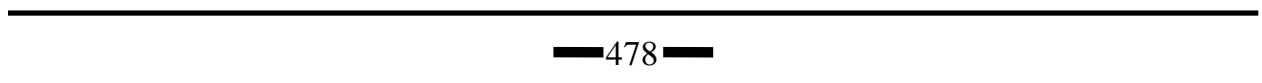




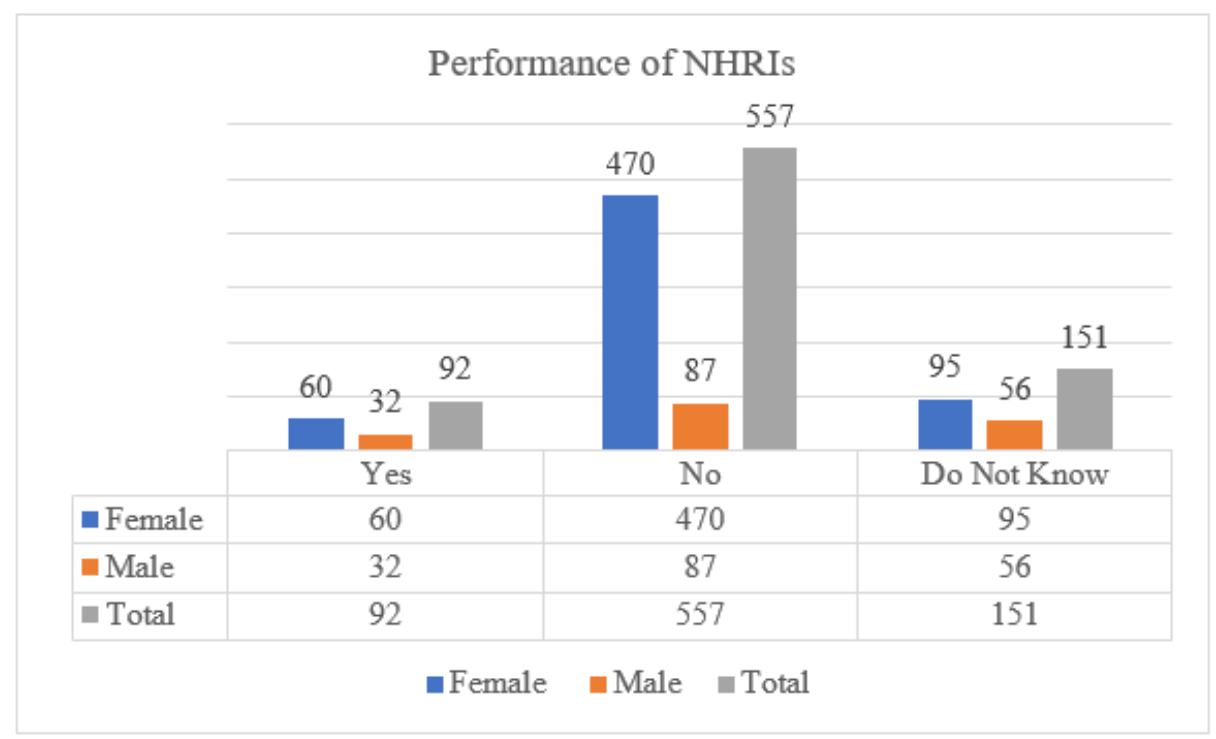

\section{Reflection of the Primary Data}

The research study has included 1000 sample population from 07 districts of Punjab province, namely: Lahore, Faisalabad, Chiniot, Multan, Narowal, Toba Take Singh, and Nankana Sahib. The study under review has specially considered the religious minorities and gender components for input from different dimensions.

A questionnaire was prepared bearing ten queries: (1) Do you believe that the religious minorities are treated equally in the social setup? (2) Do you believe that the laws and policies are treated Muslims and non-Muslims equally? (3) Do you know about the constitutional rights of religious minorities? (4) Do you think that the constitution of Pakistan has accommodated religious minorities in the right manner? (5) Do you believe that the policy of reserved quota would protect the rights of minorities and empower them? (6) Do the religious identity enhance the vulnerability of non-Muslims to enjoy fundamental freedoms? (7) Is the socio-political context is allowing the minorities to discuss their issues in the parliament? (8) Do you think that the ministries and departments concerned with religious minorities are performing as per the aspiration of minorities? (9) Do you think that the exclusive ministries and departments for minorities would address the issues of minorities? And (10) Do you think that the National Human Rights Institutions, i.e., NCSW, NCHR, RTI, and NCM, treat the issues of human rights violations of minority communities impartially? 


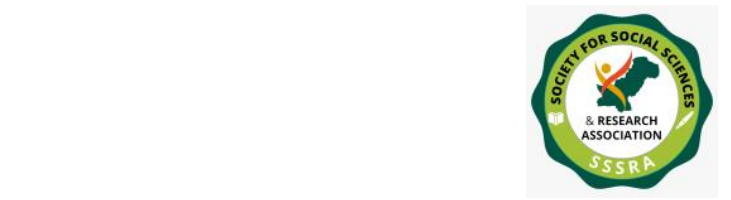

Pak. Journal of Int'L Affairs, Vol 4, Issue 4 (2021)

Minorities Rights Protection in Punjab ...

The mentioned questionnaire was distributed to NGOs, CBO, Churches, Individuals, Political Activists, and Journalists. In addition, different techniques to collect data were adopted that include focused group discussions, meetings, key informant interviews, interviews, and seminars. Six hundred sixty (660) females and three hundred and forty (340) males responded to the questionnaire.

Considering the data in hand, the query 'Equal Social Treatment' was meant to assess that the society is treating the religious minorities equally or not. Regarding this, 682 responses secured in the category of 'No' revealed that religious minorities face discrimination in societal setup and are treated as second-class citizens. Contrary to it, the category 'Yes' has secured 211 responses, meaning that middle ratio people believe that they are equal citizens and not discriminated ever. Yet, there is also a category of 'Do Not Know' which is chosen by 107 respondents that reflect that these people do not know what discrimination is.

In the next query, 'Laws and Policies are Impartial' in this regard, the high ranks of 468 respondents selected the category 'No' as per their views that Muslims and nonMuslims are treated equally in laws and policies. Besides, the middle is secured in the category 'Do Not Know' which is selected by 381 people. It shows that they do not know that the laws and policies treat all the country representatives equally. Finally, the third category of the query comes in low rank as 151 respondents mark the portion, 'Yes'. Thereby, only 151 people out of 1000 believe that laws and policies serve the people equally.

Hence, the high ratio of the respondents regarding the question' Knowledge of Fundamental Rights' ticks the portion 'No' as 652 people do not know about the constitutional rights of religious minorities. Similarly, the 'Yes' category is marked by 242 persons as they have knowledge about the rights of minorities as per the constitution. On the other side of the coin, the last category, 'Do Not Know,' secured only 106 respondents as they do not know the concept related to the query.

According to the collected data, the query 'Do Not Know' had a high ratio as 635 members selected the portion regarding the question' Inclusion of Minorities in Constitution'. Furthermore, 235 people responded to the query by marking the option 'No', which shows that they do not think that the constitution of Pakistan has suitably accommodated religious minorities. On the other hand, people who think and believe that the constitution of Pakistan has appropriately accommodated the religious minorities as 130 respondents selected the portion 'Yes'. 


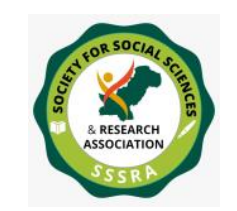

Minorities Rights Protection in Punjab ...

Considering the data, the query 'Reserved Quota for Minorities' was meant to assess that the policy of reserved quota would protect the rights of minorities and empower them or not. Regarding this, 587 responses were secured in the category of 'Yes' as it revealed that the policies of reserved quota would protect the rights of minorities and encourage them. However, contrary to it, the category 'No' has secured 231 responses that believe the policy of reserved quota would not protect the rights of minorities and empower them. Yet, there is also a category of 'Do Not Know' chosen by 182 respondents that reflect that these people do not know what the reserved quota is.

The question' Religious Identity and Vulnerability' are also asked three selected minority groups. The reason behind bearing the question in the data is to collect the respondents' views about the contribution of religious identity to increase the vulnerability of non-Muslims to enjoy fundamental freedoms. The query secured a high ratio and positive impression in the data as most 588 members selected the portion 'Yes'. Besides, 290 respondents mark the option 'No', which shows that according to their knowledge, religious identity does not contribute to increasing the vulnerability of non-Muslims to enjoy fundamental freedoms. In the same manner, the remaining portion 'Do 122 people selected no Know'.

The seventh question of the survey is about 'Socio-Political Context' in this regard, the research has investigated the component of whether the socio-political context is allowing the minorities to discuss their issues in the parliament. It was revealed that the high ratio of 549 is of those people who picked the category 'Do not know' because they do not know the question. In this respect, the category 'No' secured 340 respondents which shows that the socio-political context is not allowing the minorities to discuss their issues in the parliament. On the other hand, the portion 'Yes' was recorded by the respondents 111. This is the low ratio out of total respondents, which shows that the socio-political context allows minorities to discuss their issues in the parliament.

According to the data, the question' Performance of Institutions' was asked to know whether the ministries and departments are concerned about the religious minorities. In the same manner, 698 responses secured in the category 'No' revealed that the ministries and departments are not performing according to the acceptations of religious minorities. Furthermore, 139 people fall under the category 'Yes' according to the data. The respondents think that the ministries and departments are concerned with religious minorities and are performing as per the aspiration of minorities. Yet there is also a category of 'Do not know', which is picked by 139 respondents who come in the low rank. It shows that the people have no idea about the query.

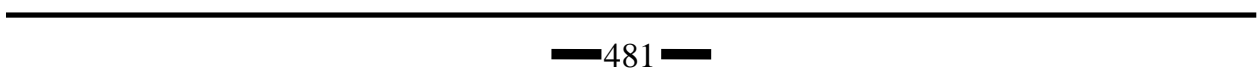




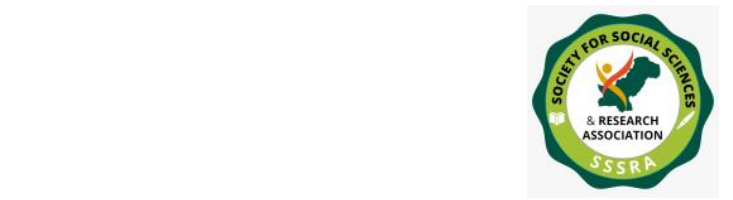

Minorities Rights Protection in Punjab ...

The question 'Exclusive Ministries/Departments' is the last question of the survey. In this regard, the research study aimed to collect the people's views about minorities. In this respect, 697 respondents were recorded in the portion 'Yes' as they think that the exclusive ministries and departments for minorities would address the issues of minorities. Therefore, the second category, 'No' secured middle rank as 214 people denied the performance of the ministries and departments working for minorities as they are not addressing their issues. Similarly, the rest of the portion 'Do not know' recorded 89 people which means they do not know the ministries and departments working on minorities.

Although, the question' Performance of NHRIs' was intended to assess that the National Human Rights Institutions are treating the religious minorities equally or not. In this regard, 706 responses secured in 'No' revealed that the religious minorities are not getting equal rights from the institutions like NCSW, NCHR, RTI, and NCM. In the same way, the second category of the query 'Do Not Know' selected by 180 respondents reflect that these people do not know the NHRIs institutions. Thereby, the category 'Yes' has secured 114 responses, which means fewer people believe that they are equal citizens and not discriminated ever.

\section{Conclusion}

The research work titled 'Minorities Rights Protection in Punjab: An Analysis of Primary Data Collected form Christian Minority' is unique as it has not only discussed the state's measures but also peeped into the plight of the rights of religious minorities. The mixed method approach further provided an opportunity to observe the theory and practice closely. The selected population sample of 800 - different groups of religious minorities additionally a comprehensive size that provided verifiable factual information to understand the impact of the policy measures on the religious minorities. As far as the protection mechanism of religious minorities is concerned, the Constitution of Pakistan, 1973, in its article 25, clearly defines the concept of equality before law and equality of citizenship and opportunities. In addition, the famous speech of our Quaid, which was delivered on 11th August 1947, in the presence of august members of the constituent assembly, is worth mentioning. It demonstrates a commitment to ensure freedom of religion or belief and a guideline for the policymakers to incorporate the diversities of land. This speech further reflects that Quaid has made promises with different groups to convince them to stay in the newly emerged state of Pakistan. There are several references available that reflect the Quaid's vision about Pakistan. There are also practical actions taken by our Quaid that demonstrate that the notion of the Two-Nation theory was only a political tool before the partition to claim a separate homeland. A land where the Muslim minority (pre-partition) feel protected and free to profess and practice their religion. 
However, once Pakistan has been come into being due to people's struggle, there is no ground to sustain the concept of the two-nation theory. As if it maintains, it encourages the division within the newly emerged Pakistan is possible. 
Questionnaire (800 Christian)

\begin{tabular}{|c|c|c|c|}
\hline 01 & \multicolumn{3}{|c|}{ Do you believe that the religious minorities are treated equally in social setup? } \\
\hline & \multicolumn{3}{|l|}{ Equal Social Treatment } \\
\hline & Yes & No & Do Not Know \\
\hline & $\mathrm{F}-102+\mathrm{M}-55=157$ & $\mathrm{~F}-465+\mathrm{M}-85=550$ & $\mathrm{~F}-58+\mathrm{M}-35=93$ \\
\hline \multirow[t]{4}{*}{02} & \multicolumn{3}{|c|}{ Do you believe that the laws and policies are treated the Muslims and non-Muslims equally? } \\
\hline & \multicolumn{3}{|c|}{ Laws and Policies are Impartial } \\
\hline & Yes & No & Do Not Know \\
\hline & $\mathrm{F}-60+\mathrm{M}-44=104$ & $\mathrm{~F}-250+\mathrm{M}-93=343$ & $\mathrm{~F}-315+\mathrm{M}-38=353$ \\
\hline \multirow[t]{4}{*}{03} & \multicolumn{3}{|c|}{ Do you know about the constitutional rights of religious minorities? } \\
\hline & \multicolumn{3}{|c|}{ Knowledge of Fundamental Rights } \\
\hline & Yes & No & Do Not Know \\
\hline & $\mathrm{F}-150+\mathrm{M}-50=200$ & $\mathrm{~F}-425+\mathrm{M}-90=515$ & $\mathrm{~F}-50+\mathrm{M}-35=85$ \\
\hline \multirow[t]{4}{*}{04} & \multicolumn{3}{|c|}{$\begin{array}{l}\text { Do you think that the constitution of Pakistan has accommodated the religious minorities in an } \\
\text { appropriate manner? }\end{array}$} \\
\hline & \multicolumn{3}{|c|}{ Inclusion of Minorities in Constitution } \\
\hline & Yes & No & Do Not Know \\
\hline & $\mathrm{F}-47+\mathrm{M}-56=103$ & $\mathrm{~F}-100+\mathrm{M}-24=124$ & $\mathrm{~F}-478+\mathrm{M}-95=573$ \\
\hline \multirow[t]{4}{*}{05} & \multicolumn{3}{|c|}{$\begin{array}{l}\text { Do you believe that the policy of reserved quota would protect the rights of minorities and } \\
\text { empower them? }\end{array}$} \\
\hline & \multicolumn{3}{|c|}{ Reserved Quota for Minorities } \\
\hline & Yes & No & Do Not Know \\
\hline & $\mathrm{F}-350+\mathrm{M}-86=436$ & $\mathrm{~F}-150+\mathrm{M}-49=199$ & $F-125+M-40=165$ \\
\hline \multirow[t]{4}{*}{06} & \multicolumn{3}{|c|}{$\begin{array}{l}\text { Do the religious identity contribute to increase vulnerability of non-Muslims to enjoy } \\
\text { fundamental freedoms? }\end{array}$} \\
\hline & \multicolumn{3}{|c|}{ Religious Identity and Vulnerability } \\
\hline & Yes & No & Do Not Know \\
\hline & $\mathrm{F}-375+\mathrm{M}-88=463$ & $\mathrm{~F}-190+\mathrm{M}-51=241$ & $\mathrm{~F}-60+\mathrm{M}-36=96$ \\
\hline \multirow[t]{4}{*}{07} & \multicolumn{3}{|c|}{$\begin{array}{l}\text { Is the socio-political context is allowing the minorities for discussing their issues in the } \\
\text { parliament? }\end{array}$} \\
\hline & \multicolumn{3}{|l|}{ Socio-Political Context } \\
\hline & Yes & No & Do Not Know \\
\hline & $\mathrm{F}-62+\mathrm{M}-18=80$ & $\mathrm{~F}-205+\mathrm{M}-72=277$ & $\mathrm{~F}-358+\mathrm{M}-85=443$ \\
\hline \multirow[t]{4}{*}{08} & \multicolumn{3}{|c|}{$\begin{array}{l}\text { Do you think that the ministries and departments concerned to religious minorities are } \\
\text { performing as per the aspiration of minorities? }\end{array}$} \\
\hline & \multicolumn{3}{|c|}{ Performance of Institutions } \\
\hline & Yes & No & Do Not Know \\
\hline & $\mathrm{F}-125+\mathrm{M}-24=149$ & $\mathrm{~F}-451+\mathrm{M}-89=540$ & $\mathrm{~F}-49+\mathrm{M}-62=111$ \\
\hline \multirow[t]{4}{*}{09} & \multicolumn{3}{|c|}{$\begin{array}{l}\text { Do you think that the exclusive ministries and departments for minorities would address the } \\
\text { issues of minorities? }\end{array}$} \\
\hline & \multicolumn{3}{|c|}{ Exclusive Ministries/Departments } \\
\hline & Yes & No & Do Not Know \\
\hline & $\mathrm{F}-450+\mathrm{M}-92=542$ & $\mathrm{~F}-150+\mathrm{M}-41=192$ & $\mathrm{~F}-25+\mathrm{M}-42=67$ \\
\hline \multirow[t]{4}{*}{10} & $\begin{array}{l}\text { Do you think that the } \\
\text { are treating the issues }\end{array}$ & $\begin{array}{l}\text { uman Rights Institutio } \\
\text { rights violations of mir }\end{array}$ & $\begin{array}{l}\text { SW, NCHR, RTI and NCM } \\
\text { nunity impartially? }\end{array}$ \\
\hline & Performance of NHRI & & \\
\hline & Yes & No & Do Not Know \\
\hline & $\mathrm{F}-60+\mathrm{M}-32=92$ & $\mathrm{~F}-470+\mathrm{M}-87=557$ & $\mathrm{~F}-95+\mathrm{M}-56=151$ \\
\hline
\end{tabular}




\section{References}

Hanif, D. K., \& Chawla, D. M. (2020). State, Religion and Religious Minorities in Pakistan: Remembering the Participation of Christians in Punjab Legislative Assembly. Pakistan Social Sciences Review, 4(2), [842-851.

Hussain, M. (2019). The Parliament of Pakistan: A History of Institution-Building and (Un)Democratic Practices, 1971-1977. Oxford University Press.

Malik, D. I. (2002). Minority Rights Group International. Minority Rights Group International.

Mehdi, T. (2010). National Assembly elections in Pakistan 1970-2008 . Karachi: Church World Service.

Mustafa, D. G., Anthony, N., \& Arslan, M. (2020). Effectiveness of Local Government System, Pro-poor Budgeting, and Policies for Marginalized Communities. Pakistan Social Sciences Review, 4(3), 535.

Mustafa, G., Ahmad, T., \& Arslan, M. (2020). Minorities in Pakistan: An Analytical Analysis of the 1973 Constitution of Islamic Republic of Pakistan. Pakistan Journal of Social Sciences, 4(2), 736-750.

Tahira, I., \& Mushtaq, A. Q. (2018). Protection of Minority Rights: An Analysis of Implementation of States, Policies, and illegalities in Pakistan. Journal of the Punjab University Historical, 8(1), 73-81. 